\title{
Differences of Cardiopulmonary Resuscitation (CPR) Teaching with Audiovisual (Video) and Demonstration Methods on Motivation To Help Victims of OHCA (Study of Vocational High School 1 Banjarbaru Students)
}

\author{
Riska Atminanta ${ }^{1}$, Abdurahman Wahid ${ }^{2}$, Oski Illiandri ${ }^{3}$ \\ \{riskaatminanta@gmail.com ${ }^{1 *}$,ns.wahid@ulm.ac.id ${ }^{2}$, oski unlam@yahoo.co.id $\left.{ }^{3}\right\}$
}

\begin{abstract}
${ }^{1}$ Student of Nursing Science Study, Faculty of Medicine Lambung Mangkurat University ${ }^{2}$ Department of Emergency Nursing Study Faculty of Medicine Lambung Mangkurat University ${ }^{3}$ Department of Biomedical Sciences Medical Study Faculty of Medicine Lambung Mangkurat University
\end{abstract}

\section{*riskaatminanta@gmail.com}

\begin{abstract}
Abstrack: The incidence of Out of Hospital Cardiac Arrest (OHCA) in Indonesia was classified as high reaching 10,000 events per year. The high mortality rate of OHCA can be prevented by teaching chain of survival in lay people and increasing their motivation to help. In increasing motivation to help, the right CPR teaching method needed to reduce mortality OHCA. This research method uses quasy experimental with the type of posttest only design. The sampling technique uses probability sampling (simple random sampling) and obtained 40 respondents. The instrument used was a motivational questionnaire. Using the t-test obtained p-value $0,000<\alpha=0.05$ means that Ho was rejected and Ha was accepted. The results of this study are effective demonstration methods to increase motivation to help victims of OHCA.
\end{abstract}

Keywords: Motivation, CPR Teaching, Demonstration Method, Audiovisual Method

\section{Introduction}

The Out of Hospital Cardiac Arrest (OHCA) incidence rate in Indonesia is still very high reaching 10,000 cardiac arrest incidence, while in South Kalimantan the incidence rate for heart disease reaches $2.2 \%$ for coronary heart disease and as much as $0.3 \%$ for failure disease heart [1]. The high mortality rate of OHCA can be prevented by the chain of survival for lay people and increasing their motivation to help [2].

One step to increase motivation is learned about what will be done. Knowledge and learning have a close relationship with the methods of learning, students can learn very well by the use of learning methods [3]. Several studies have been conducted in analyzing appropriate learning methods in CPR research on the motivation to help victims of OHCA, but there has been no research comparing audiovisual methods and demonstrations methods to CPR on motivation to help victims of OHCA.

Based on the results of a preliminary study conducted by researchers in midSeptember at Vocational High School 1 Banjarbaru, data obtained for the past 1 year (September 2017 - September 2018) had not been held training CPR at Vocational High School 1 Banjarbaru.

\section{Method}

The design of this study was a quasi-experimental type of posttest only design. The population in this study were all students of class XI (eleven) Vocational High School 1 
Banjarbaru. The sample technique used in this study was probability sampling with a simple random sampling type, as many as 40 students were selected at random and divided into 2 groups (audiovisual and demonstration). The instruments used were video, mannequins, and motivational questionnaires. The highest score is 100 and the lowest score is 20 .

The data obtained during the study were carried out by statistical tests namely unpaired t-test because of the normal type of data distribution.

\section{Results and discussion}

Age

Table 1. Frequency Distribution of Respondent Characteristics by Age $(n=40)$

\begin{tabular}{cccccc}
\hline Age & Mean & $95 \%$ CI & Median & SD & Min-Max \\
\hline Audiovisual (Video) & 16,95 & $16,76-17,13$ & 17 & 0,39 & $16-18$ \\
\hline Demonstrations & 16,95 & $16,71-17,18$ & 17 & 0,51 & $16-18$ \\
\hline
\end{tabular}

The results of the study in the two CPR teaching groups $(n=40)$ found that the characteristics of respondents based on age were most respondents aged 17 years, as many as 32 respondents, this is because the respondents in this study were vocational students of class XI, where the age of 17 years was the age which dominates in class XI, so do not be surprised if the characteristics of respondents based on the most age are respondents with the age of 17 years.

This study agrees with Thoyyibah, (2014), namely adolescents are indeed appropriate to helping victims of OHCA because adolescents learning fast and are easy to be motivated as evidenced when CPR research, respondents are very fast to be motivated in CPR research and the results of this study were obtained CPR motivation of all respondents increased [2].

\section{Gender}

Table 2 Frequency Distribution of Respondent Characteristics by Gender $(n=40)$

\begin{tabular}{llcccc}
\hline \multirow{2}{*}{ No. } & \multirow{2}{*}{ Gender } & \multicolumn{2}{c}{ Group Audiovisual (Video) } & \multicolumn{2}{c}{ Group Demonstration } \\
\cline { 3 - 6 } & & $\mathrm{N}$ & $\%$ & $\mathrm{~N}$ & $\%$ \\
\hline 1. & Male & 5 & 25 & 6 & 30 \\
2. & female & 15 & 75 & 14 & 70 \\
\hline & Total & $\mathbf{2 0}$ & $\mathbf{1 0 0}$ & $\mathbf{2 0}$ & $\mathbf{1 0 0}$ \\
\hline
\end{tabular}

Characteristics of respondents by sex in both groups (audiovisual and demonstration) in this study obtained male respondents as many as 11 respondents and female respondents as many as 29 respondents or female respondents more than male respondents. This is because the sample chosen at the time of the selection of research samples conducted by respondents from the majors of ceramic craft, textiles and catering, the number of female students more than male students.

The results of this study also found that the level of female respondent motivation to help is higher than male respondents, this is because the nature and feelings of women are more sensitive so that there is a strong motivation or encouragement to help [4]. 
Motivation for help with the audiovisual method (video)

Table 3 Motivation to Help Victims of OHCA in Ausiovisual Groups (Video)

\begin{tabular}{cccccc}
\hline Motivation & Mean & $95 \%$ CI & Median & SD & Min-Max \\
\hline Audiovisual (Video) & 74,8 & $72,57-77,02$ & 74 & 4,76 & $69-86$ \\
\hline
\end{tabular}

Based on the results of a study of 20 respondents who were given the teaching of CPRwith the audiovisual method (video) it was found that the average results of the respondents' motivation was 74.80 . The results of this study can be concluded that the teaching of CPR with audiovisual (video) method can increase the motivation of Vocational High School 1 Banjarbaru Students in assisting victims of OHCA.

From research conducted by Nugroho (2013) the level of motivation and knowledge has a close relationship, this happens because of the learning process. The form of CPR training provided to students can increase knowledge for students. increasing students' knowledge in conducting CPR also increases motivation to help victims of OHCA [5].

CPR teaching with an audiovisual method of displaying video is indeed appropriate for use in CPR discussions because video can display an action that is equipped with sound. The use of video in CPR learning can also help students understand because movements in fast videos can be arranged into slow-motion effects, related to research by Aryani et al., (2015) which refers to learning using videos that can help improve their abilities and can used repeatedly [6].

The selection of audiovisual (video) methods in CPR meetings also increases students' curiosity because the information presented is in an interesting and pleasing form. The observations of researchers discussing CPR with the audiovisual (video) method of the respondents looked enthusiastic and focus watching video.

Motivation Helps with Demonstration Methods

Table 4 Motivation to Help Victims of OHCA in Demonstration Groups

\begin{tabular}{cccccc}
\hline Motivation & Mean & $95 \%$ CI & Median & SD & Min-Max \\
\hline Demonstration & 85,55 & $83,02-88,07$ & 86,50 & 5,40 & $76-96$ \\
\hline
\end{tabular}

After being given CPR demonstration method for 20 respondents, the average motivation of respondents was 85.55. The results of this study proves CPR demonstration method can increase the motivation of Vocational High School 1 Banjarbaru Students in helping to victims of OHCA.

In line with Pratiwi's research., (2013), an effective demonstration method increases motivation because the demonstration method is a learning method that can demonstrate something in the form of a situation that is similar and real as the actual situation [7].

The observations by researchers on respondents when teaching CPR with the demonstration method found respondents seemed interested in trying to do CPR actions directly and were motivated to do CPR actions because teaching with this demonstration method uses mannequins where the teaching given is presented in the form of situations such as real circumstances so that the knowledge obtained by respondents is clearer. Lonteh et al., (2013) also revealed the same thing, the clearer the knowledge a person gets, the higher the motivation of a person to behave as he has learned [8]. 
The difference between audiovisual (video) method and demonstration against motivation to help victims of OHCA

Table 5 The Difference between CPR Teaching and the Audiovisual (Video) Method and Demonstration Against Motivation to Help Victims of OHCA

\begin{tabular}{lcccc}
\hline \multicolumn{1}{c}{ Group } & Mean & SD & Min-Max & p-value \\
\hline Audiovisual (Video) & 74,80 & 4,76 & $69-86$ & \multirow{2}{*}{0,00} \\
\hline Demonstration & 85,55 & 5,40 & $76-96$ & \\
\hline
\end{tabular}

The results of this study can be known differences in teaching CPR with audiovisual (video) methods and demonstrations of motivation to help victims of OHCA in Vocational High School 1 Banjarbaru Students with a post-test only design approach and use a word processor using t-test get a p-value of $0,000<\alpha=0.05$, which means that Ho is rejected and $\mathrm{Ha}$ is accepted. The hypothesis in this study was answered by the statement that there were differences in the teaching of CPR with audiovisual (video) methods and demonstrations of motivation to help victims of OHCA on Vocational High School 1 Banjarbaru Students. This study also shows the results of the measurement of the level of motivation of respondents who are more dominant in both groups is the group with CPR teaching using the method of domonstration.

CPR teaching with the demonstration method has a higher result compared to the audiovisual method because the demonstration method displays more events such as real circumstances and the delivery of information is two-way so that the attention of students can be focused on things that are considered important and researchers can guide respondents to think in the same direction. Whereas in the audiovisual method, the communication established is only one-way so that the respondent must be balanced with further explanation by the researcher and the respondent cannot actively involve themselves when presenting the material due to the video appearance of the respondent must wait for the video display to finish and matters deemed unclear cannot be immediately clarified until the end of the video.

Respondents using the demonstration method are also more motivated compared to respondents with audiovisual CPR teaching (video) as evidenced by respondents on the demonstration method being more active asking questions and wanting to be involved in conducting CPR, while respondents on the audiovisual method (video) only pay attention to video appearance without anyone ask questions and no one wants to be involved to try to do CPR actions.

This study is in line with research by Tipa et.al (2010) which concluded that an effective way to teach Basic Life Support (BLS) and CPR is the demonstration learning method because with the demonstration method, students will more easily accept and absorb the knowledge conveyed (9).

Other research conducted by Nurhidayati (2010) also supports the results of this study that the use of demonstration methods in learning have higher average value because the learning process of the demonstration method is more directed and students' attention can be easier to focus so that experience and the impression the student gets during the teaching process will be more inherent in the student [10].

\section{Conclusion}

The conclusion from the results of this study is that there are differences in CPR with audiovisual (video) methods and demonstrations to motivation help victims of OHCA in Vocational High School 1 Banjarbaru Students with the level of motivation of respondents 
who are more dominant in both groups is the CPR teaching group using the method domonstration. The findings of this study are expected to be useful as the selection of appropriate CPR teaching methods for motivation to help reduce the number of deaths due to OHCA.

Suggestions for further researchers are expected that this study can be continued with a sample of research with not only one group (pre-post design). The target of the research is also broader, not only schools but all community members such as government agencies to increase the number of people trained in providing assistance to victims of OHCA wherever and whenever to reduce mortality due to OHCA.

\section{References}

[1] Riskesdas. Badan Penelitian dan pengembangan kesehatan. Departemen Kesehatan Republik Indonesia. Jakarta. (2013).

[2] Toyyibah Z. DA. Pengaruh Pelatihan Bantuan Hidup Dasar Pada Remaja Terhadap Tingkat Motivasi Menolong Korban Henti Jantung. Universitas Muhammadiyah Yogyakarta. (2014).

[3] Winataputra, et.al. Strategi Belajar Mengajar. Jakarta: Universitas Terbuka (2005)

[4] Fikriana, et.al. Kualitas CPR Pada Perawat yang Mengikuti Pelatihan BLS. Jurnal Kesehatan Mesencephalon. Stikes Kepanjen. (2016).

[5] Nugroho, I. C. Hubungan tingkat pengetahuan polisi lalu tentang resusitasi jantung paru terhadap motivasi dalam memberikan pertolongan pertama gawat darurat kecelakann lalu lintas. Yogyakarta: UMY. (2013).

[6] Aryani A, Antia, Charolina A. Pengembangan Video Pembelajaran dalam Peningkatan Kemampuan Teknik Pemasangan Infus untuk Memenuhi Kompetensi Keterampilan Inti Keperawatan. E-Journal. (2015).

[7] Pratiwi SA. Peran Simulasi Bencana terhadap Kesiapsiagaan Siswa Kelas VII Dalam Menghadapi Bencana Banjir di SMP Negeri 1 Grogol Kecamatan Grogol Kabupaten Sukoharjo. E-Journal: Universitas Muhammadiyah Surakarta. (2013).

[8] Lontoh C. Pengaruh Pelatihan Teori Bantuan Hidup Dasar Terhadap Pengetahuan Resusitasi Jantung Paru Siswa-Siswi SMA Negeri 1 Toili. E-journal Keperawatan. (2013).

[9] Tipa RO, et.al. Importance of Basic Life Support Training for First and Second Year Medical Students. Journal of Medicine and Life. (2010).

[10]Nurhidayati A. Perbedaan Penerapan Metode Demonstrasi dan Audiovisual (VCD) terhadap Penguasaan Keterampilan Pertolongan Persalinan Kala II pada Mahasiswa Semester III. Jurnal KesMaDaSfca. (2010). 